\title{
A Study on Consumer Satisfaction for E-shopping in Gujarat
}

\author{
"Bhavna P. Bosamia, ${ }^{\#}$ Dr. M. H. Maisuria \\ *PhD Research Scholar, School of Commerce, Gujarat University, Ahmedabad, India. \\ bbkhatri.75@gmail.com

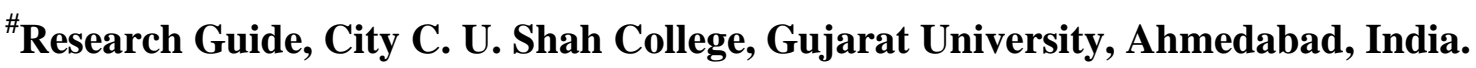 \\ mb_shaishav@yahoo.com
}

\begin{abstract}
E-shopping market in recent economy is observing high rate of growth in Asian countries especially in India. Many benefits of e-shopping have attracted customers to purchase online. Since last few months the traditional market is restricted to remain open under various guidelines described by government with the motive to keep watch on the spreading of COVIND 19. All this circumstances along with government insistence to keep open certain product lines of e-shopping sites have witnessed to encourage E-shopping business in India. To enhance current market share ecommerce firms must take care of customer satisfaction that can bring good business in present and future too. With the motive to identify the most significant factor for satisfaction current study was conducted for Gujarat region. For the analysis of the primary data descriptive statistics to explain characteristics of respondent and to indentify most vital variables to measure satisfaction of respondents factor analysis using SPSS 20 was conducted. The output of factor analysis have identified 3 factor dimension based on the degree of correlation which represent that delivery/shipping charges, price comparison facility on website and return policy are the most significant factors considered by e-shoppers while taking purchase decision and hence ecommerce firm must take care of this factors to enhance their business.
\end{abstract}

Keywords : E-shopping, Consumer satisfaction, E-shoppers.

\section{INTRODUCTION}

Evaluation of customer about the product or service after using product or service is customer satisfaction. In the academic world customer satisfaction is described as the judgment assumed out of the comparison of pre- purchase expectations with post purchase evaluation of the product or service experience (Oliver 1997). Many factors are responsible for customer satisfaction which may be related to quality, services, price etc. and it becomes utmost important to identify the most affecting factor that influences customer to re-purchase the product or services may be similar or from other product line because of derived satisfaction from past purchase. Satisfied customers also promote the product or services and positive word of mouth is effective means for advertisement. Today at global level most of the countries is struggling hard against the deadly disease of COVIND 19 and a new concept of doing business have come up that inspires the idea of working from home. The situation is now looking market to develop digitally and many government policies are also supporting to enhance ecommerce market. In this regard satisfaction level and various factors of satisfaction will directly be affected by the current recessionary trend faced by the economy. The ecommerce firm in order to retain current customers and to attract new customers must take care of the satisfaction level of the customers. With this concept the study will assist ecommerce firms to design its marketing strategy that will take care of customer satisfaction specially for Gujarat region.

\section{REVIEW OF LITERATURE}

Rashed Al Karim (2013) attempted to understand customer satisfaction in online shopping and to identify major factors that motivates customer to buy online. The Kotler and Killers (2009) Five Stage Buying Process Model and other inferential statistics were used to measure customer satisfaction. Convenience was the most encouraging factors and security issues were the most discouraging factors to shop online. In addition, the output of hypotheses revealed that despite of online shopping being convenient to all consumers, online payment system and privacy or security anxieties have observed significant impact on online shopping.

Taweerat Jiradilok, Settapong Malisuwan, Navneet Madan, and Jesada Sivaraks (Feb., 2014) utilized 
quantitative data to identify customer satisfaction that motivates them to purchase online, study has focused to find differences between experienced and inexperienced eshoppers. The study identified assurance and empathy as most affecting variables for online shopping done by both experienced and inexperienced e-shoppers. The other aspects like appropriate pricing, responsibility, website information quality, and reliability are also considered by e-shoppers and therefore it should also be added into the e-shopping websites.

A Mohamed Yunus (Dec. 2014) in his study entitled 'Customer Perception, Awareness and Satisfaction towards Online Shopping- A Study with Reference to Chennai City' attempted to study advantages, perception, awareness and satisfaction of online shoppers. According to the study the attitude of the respondents reveals that using internet for online shopping is easy. Online shoppers generally give priority to return policy and free shipping services. Demographic differences are observed for satisfaction level measured for convenience risk, financial risk and non-delivery risk. Price and convenience is important dimension considered by shoppers.

Parameswari M (2016) has conducted research entitled 'Situational Factors Influencing Preference, Motives and Satisfaction of Customers During Shopping in Select Retail Malls with Reference to Coimbatore City' with the objective to know the effects of the demographic factors that determines preference and motives of mall shoppers in Coimbatore City, The study suggested that mall managers should transform the malls into more energetic and vibrant stores providing entertainment and sophisticated atmospherics with attractive product merchandises. The outcome revealed high level of satisfaction but mall managers need to concentrate on their services that can generate increased business in future.

Dr. A B Santhi (June 2017) the study revealed the perceptions, preferences and factors that influences satisfaction of online shoppers in Tirupati Town. Respondents because of their increasing internet literacy are now ready to purchase goods of higher value through internet. The important factor that discourages respondents for online shopping is perceived risk and other variables to be considered by online firm is to take feedback from online buyers that can help to reduce faults in services of online firms.

Mr. Chander Deep Purthi \& Dr. Pramod Gupta (May, 2017) the study examined different factors that influences satisfaction level of online shoppers in India. According to the study perceived risk can be reduced by making navigation of shopping portals easier, by providing security for payment options, in order to gain customer trust must provide speedy shipping services, better presentation and categorization to make up for the missing touch and feel experience etc.
Kalia, P., Kaur, N., \& Singh, T. (2017) has explained overview examining satisfaction for e-shopping by integrating different studies in this area by providing a conceptual basis for understanding existing research. This literature review considered for the study have identified few important parameters that influences e-satisfaction of customer which site design, reliability, information, security, perceived usefulness, ease of use, convenience, and e-service quality.

Richu m. Juneja (may, 2018) in her thesis on 'Customer Satisfaction and Customer Loyalty in Online Shopping: A Study of Surat City' has examined satisfaction and loyalty of customer in online shopping in Surat City.The outcome of the study wrap up that different variables have influenced the satisfaction level of customers in online shopping in Surat City. For e-shoppers price and quality of the product, and customer service offered by e-stores significantly affect satisfaction of the customers. Other important variables prioritize by e-shoppers are logistic and delivery, and trust and efficiency. In a nutshell the study concluded that customers are moderately satisfied with respect different variables measured in the study. Customers are more satisfied with apparels and beauty products purchased online. It was identified from the study that expectations from online stores are higher than what they perceive from their current purchase experiences.

Thummala Sudheer (Feb., 2019) in his study 'Consumer Attitude towards Online Shopping' attempted to identify priority and satisfaction level of online shoppers according to the study tier-II cities (Guntur, Nellore, Vijayawada, and Visakhapatnam) in Andhra Pradesh observed increasing trend for online shopping. Important variable considered by e-shoppers were convenience of the shopping, product quality, discounts and offers providing by the online shoppers. Factors that attracted e-shoppers includes Customer Reviews, Diversity of products, Product features, Product characteristics, Information about Product updates, Comparative analysis of prices, Temporal dynamics of commodity price changes, 24/7 customer service, Easy replacement, Easy return policy, reducing waiting time, Prompt delivery, shipping costs, Ratings of online stores, and No cost EMI. Study concluded that social media and positive word of mouth are effective mode of promotion for online business.

\section{Objective of the study}

To identify significant factors that influences satisfaction level of E-shoppers

\section{Hypothesis}

H0 : There are no latent underlying structures for satisfaction level of E-shoppers and that all variable load equally 
H1 : There are latent underlying structures for satisfaction level of E-shoppers and that all variable do not load equally

\section{RESEARCH MeTHODOLOGY}

The research is based on both primary data and secondary data. Secondary data comes from various published data, journals, websites etc. Primary data are collected from different region of Gujarat using convenience sampling technique through structured questionnaire. For the analysis of the data and information quantitative research methodologies i.e. frequency analysis and factor analysis with Principle Component Analysis using Varimex Rotation in SPSS 20 is conducted to identify significance of the factors under study.

Table 1 Frequency Analysis of Demographics

\begin{tabular}{|c|c|c|c|}
\hline S. No. & Demographics & Frequency & Percentage \\
\hline \multirow[t]{6}{*}{1} & \multicolumn{3}{|l|}{ Age } \\
\hline & $18-25$ & 38 & 31.9 \\
\hline & $26-35$ & 40 & 33.6 \\
\hline & $36-45$ & 29 & 24.4 \\
\hline & 46 years and above & 12 & 10.1 \\
\hline & Total & 119 & 100.0 \\
\hline \multirow[t]{4}{*}{2} & \multicolumn{3}{|l|}{ Gender } \\
\hline & Male & 75 & 63.0 \\
\hline & Female & 44 & 37.0 \\
\hline & Total & 119 & 100.0 \\
\hline \multirow[t]{6}{*}{3} & \multicolumn{3}{|l|}{ Education } \\
\hline & Up to Higher Secondary & 10 & 8.4 \\
\hline & Graduates & 38 & 31.9 \\
\hline & Post Graduates & 56 & 47.1 \\
\hline & Others & 15 & 12.6 \\
\hline & Total & 119 & 100.0 \\
\hline \multirow[t]{4}{*}{4} & \multicolumn{3}{|l|}{ Marital Status } \\
\hline & Married & 81 & 68.1 \\
\hline & Unmarried & 38 & 31.9 \\
\hline & Total & 119 & 100.0 \\
\hline \multirow[t]{6}{*}{5} & \multicolumn{3}{|l|}{ Profession } \\
\hline & SelfEmployed/Business & 26 & 21.8 \\
\hline & Employed & 64 & 53.8 \\
\hline & Student & 19 & 16.0 \\
\hline & Housewife & 10 & 8.4 \\
\hline & Total & 119 & 100.0 \\
\hline \multirow[t]{7}{*}{6} & \multicolumn{3}{|l|}{ Income } \\
\hline & less than 20000 & 28 & 23.5 \\
\hline & $20000-40000$ & 34 & 28.6 \\
\hline & $40000-60000$ & 15 & 12.6 \\
\hline & above 60000 & 28 & 23.5 \\
\hline & no income & 14 & 11.8 \\
\hline & Total & 119 & 100.0 \\
\hline
\end{tabular}

The above Table 1 describes demographic profile of respondents which shows that majority of the respondents fall between the age group of 26 - 35 years, $63 \%$ of respondents are male, $47.1 \%$ of them are post graduate, $68.1 \%$ are married, $53.8 \%$ are employed and $28.6 \%$ of them have income between Rs. 20000 to Rs. 40000.
Table 2 Online Shopping Sites Preferred by Respondents For E-shopping

\begin{tabular}{|c|c|c|c|}
\hline \multirow{2}{*}{ Sites Preferred for E-shopping } & \multicolumn{2}{|c|}{ Responses } & \multirow{2}{*}{$\begin{array}{l}\text { Percent of } \\
\text { Cases }\end{array}$} \\
\hline & $\mathbf{N}$ & Percent & \\
\hline Amazon & 103 & $26.1 \%$ & $86.6 \%$ \\
\hline Flipkart & 93 & $23.5 \%$ & $78.2 \%$ \\
\hline Myntra & 32 & $8.1 \%$ & $26.9 \%$ \\
\hline Snapdeal & 37 & $9.4 \%$ & $31.1 \%$ \\
\hline Shopclues & 16 & $4.1 \%$ & $13.4 \%$ \\
\hline Tatacliq & 6 & $1.5 \%$ & $5.0 \%$ \\
\hline Paytm Mall & 34 & $8.6 \%$ & $28.6 \%$ \\
\hline Jabong & 11 & $2.8 \%$ & $9.2 \%$ \\
\hline Ajio & 11 & $2.8 \%$ & $9.2 \%$ \\
\hline LimeRoad & 7 & $1.8 \%$ & $5.9 \%$ \\
\hline Club Factory & 34 & $8.6 \%$ & $28.6 \%$ \\
\hline Others & 11 & $2.8 \%$ & $9.2 \%$ \\
\hline Total & 395 & $100.0 \%$ & $331.9 \%$ \\
\hline
\end{tabular}

The above Table 2 exhibits that Amazon and Flipkart is the most popular sites used by respondents to purchase online in Gujarat.

Table 3 KMO and Bartlett's Test

\begin{tabular}{|l|l|l|}
\hline Kaiser-Meyer-Olkin Measure of Sampling Adequacy. & .917 \\
\hline \multirow{3}{*}{ Bartlett's Test of Sphericity } & Approx. Chi-Square & 1490.894 \\
\cline { 2 - 3 } & Df & 120 \\
\cline { 2 - 3 } & Sig. & .000 \\
\hline
\end{tabular}

Table 3 representing Bartlett's test of sphericity tests the hypothesis that the correlation matrix is an identity matrix. If the test value is large and the significancelevel is small $(<0.05)$, the hypothesis that the variables are independent can be rejected. In the present analysis, the Bartlett's test of sphericity yielded a value of 1490.894 and an associated level of significance smaller than 0.001. Thus, the hypothesis that the correlation matrix is an identity matrix is rejected. Thus indicating that the data best fits to conduct Factor Analysis.

Table 4 Summary of Factor Analysis for 16 items resulted in to 3 dimension

\begin{tabular}{|c|c|c|c|c|}
\hline Factor and Items & $\begin{array}{c}\text { Eigen } \\
\text { Values }\end{array}$ & $\begin{array}{c}\text { Factor } \\
\text { Loadings }\end{array}$ & $\begin{array}{c}\text { Variance } \\
(\%)\end{array}$ & $\begin{array}{c}\text { Cumulative } \\
\text { Variance }(\%)\end{array}$ \\
\hline $\begin{array}{lr}\text { E-shops } & \text { Offer } \\
\text { (Cronbach's } & \text { Alpha } \\
0.903) & \end{array}$ & 9.153 & & 25.014 & 25.014 \\
\hline $\begin{array}{l}\text { Delivery/shipping } \\
\text { Charges }\end{array}$ & & .802 & & \\
\hline $\begin{array}{l}\text { Delivery/Shipping } \\
\text { period }\end{array}$ & & .771 & & \\
\hline $\begin{array}{ll}\text { Range/variety } & \text { of } \\
\text { product available } & \end{array}$ & & .738 & & \\
\hline Discount offers & & .612 & & \\
\hline Price of the product & & .602 & & \\
\hline Quality of product & & .556 & & \\
\hline Special festival offers & & .521 & & \\
\hline $\begin{array}{lr}\text { Website } & \text { Portrayal } \\
\text { (Cronbach's } & \text { Alpha } \\
0.907) & \end{array}$ & 1.231 & & 23.598 & 48.611 \\
\hline $\begin{array}{l}\text { Price comparison } \\
\text { facility on website }\end{array}$ & & .797 & & \\
\hline $\begin{array}{l}\text { Product comparison } \\
\text { facility on website }\end{array}$ & & .765 & & \\
\hline $\begin{array}{l}\text { Product description } \\
\text { given on website }\end{array}$ & & .733 & & \\
\hline $\begin{array}{l}\text { Product demonstration } \\
\text { presenting how to use a }\end{array}$ & & .732 & & \\
\hline
\end{tabular}




\begin{tabular}{|l|l|l|l|l|}
\hline product & & & & \\
\hline $\begin{array}{l}\text { Product review and } \\
\text { rating available on } \\
\text { website Sale Policy }\end{array}$ & & .726 & & \\
\hline $\begin{array}{l}\text { After Sale } \\
\text { (Cronbach's Alpha } \\
\text { 0.896) }\end{array}$ & 1.091 & & 23.104 & 71.715 \\
\hline Return policy & & .829 & & \\
\hline Refund facility & & .770 & & \\
\hline Payment facility & & .756 & & \\
\hline $\begin{array}{l}\text { Product packing } \\
\text { considering safety of } \\
\text { product during transit }\end{array}$ & & .561 & & \\
\hline
\end{tabular}

The 16 variables identified to measure satisfaction level for online shopping were summarized through Factor Analysis using SPSS 20 in order to reduce data sets by identifying linear composites that preserves original data sets. The data were subject to principal component analysis through varimax rotation that have identified three major factors which comprises of factor 1 as E-shops offers that covers offering provided by online retail outlets, factor 2 as website portrayal which describes satisfaction generated through website content of eshopping sites and finally factor 3 represented as After Sale Policy which covers the policy and facility provided after the purchase decision. The above table 4 depicts factor loadings greater than 0.5 with Cronbach's Alpha 0.903 for factor $1,0.907$ for factor 2 and 0.896 for factor 3 shows the significance of the data. The Eigen value greater than one identified for three factors shows cumulative variance which represents that factors identified covers $71.72 \%$ of the variables.

The most important variable for factor 1 is Delivery/shipping Charges describing factor loading of .802 , for factor 2 Price comparison facility on website with factor loading of .797 and for factor 3 Return policy having factor loading .829 .

\section{CONCLUSION}

The major addition of the study is to identify most significant factors of customer satisfaction with regards to online shopping in Gujarat region. All the variables measured and considered for the study shows higher correlation between each other which reveals that all the factors are important and online shopping firm must take care of this variables. The three dimension identified through factor analysis describes $71.72 \%$ of the variance and remaining 13 factors together explains $28.28 \%$ of the variance. Thus a model with three factors is sufficient to represent the data. The grouping of factors is entirely a subjective decision, aimed to reduce the number of extracted factors to a smaller, more manageable, and ultimately more meaningful set of factors. Given that the present factor structure appears to be represented by three dimensions measuring satisfaction level of e-shoppers which concludes E-shops offers as factor 1 which describes seven factors related to offers provided by eshopping firms, Website portrayal as factor 2 covering five related factors that Ecommerce firm must consider while deciding criteria for depicting data on website and After sale policy as factor 3 that have identified four related factors that ecommerce company should consider to promote e-shopping among customers.

\section{REFERENCES}

[1] Everitt, S. L. (2004). A Handbook of Statistical Analyses Using SPSS. Newyork: Chapman \& Hall/CRC Press Company.

[2] Juneja, R. M. (2018, May). Shodhganga inflibnet. Retrieved May 29, 2020, from shodhganga website: http://hdl.handle.net/10603/285920

[3] Kothari, C. R. (2004). Research Methodology Methods and Techniques. New Delhi: New Age International Publisher.

[4] Murthy, C. S. (2018). e-Commerce Concepts. Models. Strategies. Mumbai: Himalaya Publishing House

[5] Nandgopal R., K. A. (2008). Research Methods in Business. New Delhi: Excel Books.

[6] Parameswari, M. (2016). Shodhganga Inflibnet. Retrieved May 29, 2020, from Shodhganga website: http://hdl.handle.net/10603/235895

[7] Robert, H. (2006). Handbook of Univariate and Multivariate Data ANalysis and Interpretation with SPSS. NewYork: Chapman \& Hall/CRC Press Company.

[8] Sudheer, T. (2019, February). Shodhganga Inflibnet. Retrieved May 29, 2020, from Shodhganga website: 4 http://hdl.handle.net/10603/284507

[9] Yunus, A. M. (2014, December). Shodhganga Inflibnet. Retrieved May 29, 2020, from Shodhganga: http://hdl.handle.net/10603/200056

[10] Al Karim, R. (2013). Customer Satisfaction in Online Shopping: a study into the reasons for motivations and inhibitions. IOSR Journal of Business and Management, 11(6), 13-20. https://doi.org/10.9790/487x-1161320

[11] Jiradilok, T., Malisuwan, S., Madan, N., \& Sivaraks, J. (2014). The Impact of Customer Satisfaction on Online Purchasing: A Case Study Analysis in Thailand. Journal of Economics, Business and Management, 2(1), 5-11. https://doi.org/10.7763/joebm.2014.v2.89

[12] Kalia, P., Kaur, N., \& Singh, T. (2017). Consumer satisfaction in eshopping: An overview. Indian Journal of Economics and Development, 13(2a), 569. https://doi.org/10.5958/23220430.2017 .00132 .9

[13] Purthi, C. D., \& Gupta, P. (2017). THE IMPACT OF ONLINE SHOPPING ON CUSTOMER SATISFACTION IN Mr . Chander Deep Purthi , ( Research Scholar ), 5(5), 1-11.

[14] Santhi, D. A. B. (2017). A Study on the Customer Satisfaction towards Online Shopping In Tirupati Town. IOSR Journal of Business and Management, 19(06), 12-16. https://doi.org/10.9790/487x-1906011216 